\title{
Effects of pesticides on rural workers: haematological parameters and symptomalogical reports
}

\author{
Efeitos dos pesticidas sobre trabalhadores rurais: parâmetros \\ hematológicos e relatos sintomatológicos
}

Juliana Dalbó (https://orcid.org/0000-0001-5088-5466) ${ }^{1}$

Lívia Alves Filgueiras (https://orcid.org/0000-0001-5689-4961) ${ }^{2}$

Anderson Nogueira Mendes (https://orcid.org/0000-0002-9778-3667) ${ }^{2}$

${ }^{1}$ Rede Nordeste de Biotecnologia, Universidade Federal do Espírito Santo. Av. Fernando Ferrari 514, Goiabeiras. 29075-910

Vitória ES Brasil.

${ }^{2}$ Departamento de Biofísica e Fisiologia, Universidade Federal do Piauí. Teresina Piauí Brasil.

anderson.mendes@

gmail.com

\begin{abstract}
Exposure to pesticides by the rural population is increasing worldwide. Pesticides can induce the development of different diseases such as cancer and diseases of the central nervous system. This study analysed the clinical symptoms and haematological changes of a rural population in Conceição do Castelo, Espirito Santo, Brazil. For evaluation of symptomatology exposure to pesticides, 142 rural workers were interviewed. Of these, 22 workers were selected for haematological tests randomly as to evaluate haematological changes during the period of exposure to pesticides. Haematological analyses showed that erythrocytes, haemoglobin, haematocrit, mean corpuscular (VCM) volume, mean corpuscular haemoglobin $(\mathrm{MCH})$, mean corpuscular haemoglobin concentration (MCHC) are in accordance with the reference intervals in haematology. Variations in the concentrations of rods and neutrophils indicates that exposure to pesticides increases the amount of those cells. Haematological disorders in rural workers exposed to pesticides can be correlated with reported symptoms. The results described in this study are relevant to the health public and reinforce the concern about the indiscriminate use of pesticides.
\end{abstract}

Key words Haematological disorders, Health of rural workers, Human poisoning, Organophosphorus, Pesticides
Resumo A exposição a pesticidas pela população rural está crescendo em todo o mundo. Os pesticidas podem induzir o desenvolvimento de diferentes doenças, como o cancer e as do sistema nervoso central. Este estudo analisou os sintomas clínicos e alteraçães hematológicas de uma população rural em Conceição do Castelo, Espirito Santo, Brasil. Para a avaliação da exposição a pesticidas $e$ sintomatologias, 142 trabalhadores rurais foram entrevistados. Destes, 22 trabalhadores foram selecionados de randomicamente para testes hematológicos e avaliação de alterações hematológicas durante o período de exposição a pesticidas. Análises hematológicas mostraram que eritrócitos, hemoglobina, hematócrito, volume corpuscular médio (VCM), hemoglobina corpuscular média (HCM), concentração de hemoglobina corpuscular média (CHCM) estão em conformidade com os intervalos de referência. As variações nas concentrações de bastonetes e neutrófilos indicam que a exposição a pesticidas aumenta a quantidade dessas células. Alterações hematológicas em trabalhadores rurais expostos a pesticidas podem ser correlacionados com alguns sintomas relatados. Os resultados descritos neste estudo são relevantes para a saúde pública e para reforçar a preocupação com o uso indiscriminado de pesticidas.

Palavras-chave Alterações hematológicas, Saúde do trabalhador rural, Intoxicação humana, Organofosforados, Pesticidas 


\section{Introduction}

Pesticides have been used since the 1950s in Bra$\mathrm{zil}^{1,2}$. Between 2000 and 2010, the use of pesticides increased 93\% worldwide, while in Brazil, this percentage reached $190 \%{ }^{3}$. It is estimated that approximately 25 million workers are exposed to pesticides in developing countries alone $\mathrm{e}^{4}$. Brazil consumption doubled reaching the alarming index of 190\%, making Brazil the leader of the world rankings since $2008^{5}$.

The organophosphorus class is a particularly relevant group of pesticides, as they have been in use as insecticides since $1940^{6}$. Organophosphorus are commercially used to control agricultural pests and arthropod vectors of disease, for domestic purposes ${ }^{7,8}$. Insecticides may cause a variety of toxic effects on different living beings in the field, mainly due to the presence of residual concentrations arising from the repeated use of chemicals?. Exposures to pesticides can be overt or subacute, and the effects range from acute to chronic toxicity?

Given the different forms of application and use of these products, a large number of people around the world are routinely exposed to toxic levels. In 2008, pesticides were the ninth most common substance reported in poison control centres, and approximately $45 \%$ of all pesticide poisonings were reported in children ${ }^{10}$.

Although pesticides are widely used as a crop protection product, they can have significant adverse effects on "non-target" species, including humans $s^{6}$. These adverse effects include possible long-term effects of chronic low-level exposure, developmental toxicity and neurotoxicity, in addition to possible pathophysiological actions that have not yet been described in the literature ${ }^{8,11}$. These pathophysiological may be preceded by general symptoms, such as eye irritation, lacrimation, headache, skin lesions, nausea, dyspnoea, tingling, cramps, muscle pain, depression, and others ${ }^{3,6,12}$. Long-term exposure can cause contact dermatitis symptoms, such as erythema, burning, itching, vesicles and eczema, and corrosive lesions of the oral, oesophageal and gastric mucosa ${ }^{9,13-16}$.

The damages caused by pesticides constitute a very serious public health problem, particularly regarding the health of both farmers and consumers ${ }^{3}$. These compounds can be absorbed through the skin, mucous membranes, gastrointestinal tract and respiratory causing poisoning in farm workers, producing high morbidity and mortality ${ }^{17}$. Less severe exposures may cause excessive salivation, lacrimation, and frequent uri- nation, along with excessive sweating, impaired gastrointestinal motility and vomiting followed by paralysis ${ }^{12,17}$. Exposure to high doses of and acute exposure to pesticides can result in death due to respiratory failure ${ }^{8}$.

Organophosphorus is associated with neurotoxic effects in which cognitive functions such as psychomotor speed, performance of functions, visual skills and memory are affected. Exposure may result in Parkinson's disease, Alzheimer's disease, amyotrophic lateral sclerosis, depression, suicide $^{10,14,18,19}$. Organophosphorus can induce the formation of free radicals that interact with blood cells by changing haematological parameters ${ }^{20}$.

The vast majority of papers published in the literature associate organophosphorus with inhibition of acetyl cholinesterase $e^{6,8,12,15-17,19}$, but do not discuss possible haematological changes in humans that are continuously exposed to such products. Thus, it is necessary to investigate haematological parameters and correlate possible effects of organophosphorus in humans.

Despite the implementation of the Programme for Pesticide Residue Analysis in Food, several farmers and Brazilian consumers are exposed to pesticides, which increases the likelihood of developing diseases resulting from the contact with these products ${ }^{3}$. Pomeranian communities from the brazilian State of Espírito Santo, such as those from the regions of Santa Tereza and Santa Maria de Jequitibá, usually use pesticides indiscriminately ${ }^{2}$. Accordingly, this study aimed to investigate and trace the profile of a community from the south of Espírito Santo regarding the exposure to and use of pesticides to investigate possible symptoms and pathophysiological characteristics associated with mild or overexposure to organophosphorus and other pesticides.

\section{Materials and methods}

\section{Epidemiological study of the population using an assessment questionnaire}

The study population consists of several family groups, with a total of 142 people residing in the Mata Fria community, in the rural area of Conceição do Castelo-Espírito Santo, who use pesticides in agricultural activities. The participants included individuals of both genders aged between 15 and 82 years old. They were evaluated with a questionnaire aimed at identifying possi- 
ble correlations between exposure to pesticides and the symptoms arising from this exposure.

\section{Blood collection and complete blood count}

Rural workers were randomly selected from the study population for the blood tests before and after the growing season. During the harvest period, 22 workers were tested. After the end of the harvest period, only 22 workers were tested because they were the only ones who had direct contact with pesticides during this period. The same 22 rural workers were used for analyzes before and after harvest.

Peripheral blood was collected from the median cubical vein of the participants with a $3-\mathrm{mL}$ syringe and placed in 3-mL tubes containing 5\% ethylenediaminetetraacetic acid (EDTA). After collection, the blood was placed into a homogeniser, followed by a blood smear. For that purpose, a small amount of blood that was in the test tube was pipetted onto a slide labelled with the rural workers' identification data. Another slide (spreader) was used at an angle of $45^{\circ}$ to draw back against the drop of blood, filling the slide to the edges and obtaining a smear.

The slides with the smears were staining by immersing them in fixative solution with ethanol (10s). Next, the slides were removed and immersed in haematoxylin for visualisation of blood cells (10s) and then in eosin for staining leucocytes (15s). Slides were visualised on a Nikon Eclipse E200 ${ }^{\circledR}$ microscope. The blood cell count was performed in the BC-2800 Mindray ${ }^{\circledR}$ apparatus using the whole blood collected in EDTA-containing tubes to check for changes in blood cell count. Serum ALT, AST and butyrylcholinesterase (BChE) were analyzed using commercial Dolles brand kit.

This study was conducted according to the recommendations of the Resolution 466/12CNS/ MS and was approved by the Human Research Ethics Committee of the Federal University of Espírito Santo.

\section{Statistical analysis}

All variables were compared using the Student $t$ test ( $\mathrm{P}$-valor $<0.05$ was considered statistically significant). Data were analysed using GraphPad Instat software (GraphPad Software Inc., version 6.0). Values are presented as mean \pm s.d. Differences between experimental groups were evaluated by the two-tailed unpaired Student's $t$ test. $\mathrm{A}^{\star} \mathrm{p}$ value $<0.05,{ }^{\star *} \mathrm{p}$ value $<0.01,{ }^{\star \star *} \mathrm{p}<$
0.001 and ${ }^{* * * *} \mathrm{p}<0.0001$ were considered statistically significant.

\section{Results}

Table 1 shows the main pesticides used by farmers in the region of Conceição do Castelo, Espírito Santo. Roundup is used extensively as an herbicide for all farmers in order to combat the growth of weeds. The Aminol and Gramoxone pesticides are used also in large quantities by some farmers. Farmers still use insecticides and fungicides as the Verdadeiro and Lannate. Variability of chemical groups of pesticides is an item that should be considered as interference in the health of rural workers who are directly exposed to these products.

Table 2 shows the level of education that rural workers have regarding the handling of pesticides. As described in section 2, workers answered a questionnaire in order to assess whether they know to handle properly the pesticides and what the purpose of use of purchased pesticides. According to Table 2, they do not receive information about the dangers of pesticide use in the field and what damage pesticides can cause to the health of workers. The way of manipulation of pesticides is inadequate and much of the population works with pesticides for over 10 years. The workers do not adequately utilize safety equipment for handling of pesticides.

Table 3 shows the general information on the exposed workers. Rural workers have low education, with most males above 30 years. Most workers are not smokers and do not consume alcohol.

Table 4 shows which symptomatology rural workers say present, especially when they are in the collection, handling or not pesticides. The variability of symptoms is extensive. However, most workers complain of eye irritation, headaches, joint pain, muscle pain.

Figure 1 shows the haematological analysis performed on 22 rural workers before and after the harvest period, to evaluate possible interactions of pesticides with blood cells. The hematologic analyzes show slight variation in leucocyte number, band neutrophils, neutrophils and platelets.

\section{Discussion}

Brazil is the third largest consumer of crop protection products in the world and the first in Latin America. The Southeast and South of Brazil 
Table 1. Pesticides used by the population in Conceição do Castelo, Espírito Santo. The table describes the trademarks (Brand name) used by rural workers, the most common Class of pesticides used, the Chemical group of the commercial pesticides used, the Manufacturers of pesticides and the number of workers (\%) using each product as a percentage.

\begin{tabular}{|c|c|c|c|c|}
\hline $\begin{array}{c}\text { Brand name } \\
\text { Active principle }\end{array}$ & Class & Chemical group & Manufacturer & $\%$ \\
\hline $\begin{array}{l}\text { Roundup } \\
\mathrm{N} \text {-(phosphonomethyl)glycine }\end{array}$ & Herbicide & Organophosphorus & $\begin{array}{l}\text { Monsanto Company / } \\
\text { USA - United States }\end{array}$ & 100 \\
\hline $\begin{array}{l}\text { Aminol } \\
\text { 2,4-dichlorophenoxyacetic acid }\end{array}$ & Herbicide & Dipyridylium & $\begin{array}{l}\text { Syngenta Limited - } \\
\text { United Kingdom }\end{array}$ & 56.3 \\
\hline $\begin{array}{l}\text { Gramoxone } \\
\text { 1,11-dimethyl 4,41-bipyridyl } \\
\text { dichloride }\end{array}$ & Herbicide & Phenoxyacetic acids & $\begin{array}{l}\text { Milenia agro ciências } \\
\text { S/A - Londrina }\end{array}$ & 47.2 \\
\hline $\begin{array}{l}\text { Folicur } \\
\text { (RS)-1-p-chlorophenyl-4,4-dimethyl- } \\
\text { 3-(1H-1,2,4-triazol-1-ylmethyl) } \\
\text { pentan-3-ol }\end{array}$ & Fungicide & Triazole & $\begin{array}{l}\text { Bayer Crop Science } \\
\text { AG - Germany }\end{array}$ & 5.6 \\
\hline $\begin{array}{l}\text { Fegatex } \\
\text { benzalkonium chloride }\end{array}$ & $\begin{array}{l}\text { Fungicide, } \\
\text { Bactericide } \\
\text { and } \\
\text { sporicide }\end{array}$ & $\begin{array}{l}\text { Ethylbenzalkonium } \\
\text { chloride }\end{array}$ & $\begin{array}{l}\text { PRTrade Tecnologia } \\
\text { Indústria Química e } \\
\text { Farmacêutica Ltda - } \\
\text { São Paulo }\end{array}$ & 5.6 \\
\hline $\begin{array}{l}\text { Flex } \\
\text { Diphenyl ether }\end{array}$ & Insecticide & Oxime methylcarbamate & $\begin{array}{l}\text { E. I. du Pont La Port } \\
\text { Plant - Texas }\end{array}$ & 5.6 \\
\hline $\begin{array}{l}\text { Targa } \\
\text { Ethyl (R)-2-[4-(6-chloroquinoxalin-2- } \\
\text { yloxy)penoxy]propionate }\end{array}$ & $\begin{array}{l}\text { Insecticide } \\
\text { and } \\
\text { fungicide }\end{array}$ & $\begin{array}{l}\text { Neonicotinoid }+ \\
\text { Triazole }\end{array}$ & $\begin{array}{l}\text { Cyproconazole } \\
\text { technical: Switzerland } \\
\text { Bayer AG }\end{array}$ & 4.9 \\
\hline $\begin{array}{l}\text { Verdadero } \\
\text { 3-(2-chloro-1,3-thiazol-5-ylmethyl)- } \\
\text { 5-mehtyl-1,3,5-oxadiazinan-4-ylidene } \\
\text { (nitro)amine } \\
+ \\
\text { (2RS,3RS,2RS,3SR)-2-( } \\
\text { 4-chlorophenyl)-3-cyclopropyl-1- } \\
\text { (1H-1,2,4-triazol-1-yl)butan-2-ol }\end{array}$ & Herbicide & Diphenyl ether & $\begin{array}{l}\text { Zhongzha Branch } \\
\text { Jiangsu Changqing } \\
\text { Agrochemicals Co. } \\
\text { Ltd. - China }\end{array}$ & 0.7 \\
\hline $\begin{array}{l}\text { Lannate } \\
\text { S-methyl N-(methylcarbamoyloxy) } \\
\text { thioacetimidate }\end{array}$ & Herbicide & $\begin{array}{l}\text { Aryloxyphenoxypropionic } \\
\text { acid }\end{array}$ & $\begin{array}{l}\text { Nissan chemical } \\
\text { industries, LTD - } \\
\text { Japan }\end{array}$ & 0.7 \\
\hline
\end{tabular}

consume approximately $38.9 \%$ and $31.2 \%$, respectively, of the amount of these products used in the entire country ${ }^{21}$. These regions are the largest Brazilian consumers and are, therefore, the focus of attention of surveillance agencies for the control of the indiscriminate use of such products. According to the Brazilian Institute of Environment and Renewable Natural Resources (IBAMA), Brazil primarily consumes the herbicides glyphosate (76\%), 2,4-dichloropheoxyacetic acid (2,4-D) and atrazine; the fungicides mineral oil, sulphur, and carbendazim; and the insecticides cypermethrin (57\%), methamidophos and acephate ${ }^{22}$.

The commercial product Roundup is the most used herbicide in Conceição do Castelo, as showed in Table 1 . Roundup contains $41 \%$ glyphosate as the isopropylamine salt and polyoxyethyleneamine (POEA) $15 \%{ }^{23}$. This product is considered very efficient in combating weeds in coffee plantations. According to the assessment, coffee growing is the main agricultural activity in the municipality. During the course of the research, it was identified that the rural community of Conceição do Castelo has direct and indirect contact with pesticides of the chemical groups: organophosphorus; triazoles; pyrethroids and carbamates.

The rural workers replace organophosphorus with the chemicals phenoxyacetic acid or bipyridylium to control weeds in corn and bean plantations because, after seed germination, organophosphorus can kill the corn and/or bean 
Table 2. Characteristics of the farms and pesticide exposure among the rural workers from Conceição do Castelo.

\begin{tabular}{|c|c|c|}
\hline Variable & $\mathbf{N}$ & $\%$ \\
\hline \multicolumn{3}{|l|}{ Receive an agronomic prescription: } \\
\hline Never/almost never & 137 & 96.5 \\
\hline Sometimes & 5 & 3.5 \\
\hline \multicolumn{3}{|l|}{ Places where the pesticides are } \\
\hline Agricultural stores & 9 & 6.4 \\
\hline Other municipalities & & \\
\hline \multicolumn{3}{|l|}{ Disposal of the empty containers: } \\
\hline Selective collection & 70 & 49.3 \\
\hline Burned & 29 & 20.4 \\
\hline Stored & 65 & 45.7 \\
\hline \multicolumn{3}{|l|}{ Mode of exposure: } \\
\hline Preparing the spray mix & 103 & 72.5 \\
\hline Helping with the application & 104 & 73.2 \\
\hline Cleaning the equipment & 128 & 90.1 \\
\hline Contaminated clothing & 111 & 78.1 \\
\hline Re-entering a contaminated area & 142 & 100 \\
\hline \multicolumn{3}{|l|}{ Technical guidelines for the use of } \\
\hline Directly from the vendor & 12 & 8.4 \\
\hline Other person on the property & 67 & 47.2 \\
\hline Neighbours and other friends & & \\
\hline \multicolumn{3}{|l|}{ Number of years of exposure to } \\
\hline pesticides: & 29 & 20.4 \\
\hline 2 to 10 & 75 & 52.9 \\
\hline 11 to 20 & 38 & 26.7 \\
\hline 21 to 30 & & \\
\hline \multicolumn{3}{|l|}{ PPE used: } \\
\hline None & 69 & 48.6 \\
\hline Boots & 73 & 51.4 \\
\hline Hat & 2 & 1.4 \\
\hline Protective clothing & 7 & 4.9 \\
\hline Gloves & 9 & 6.3 \\
\hline Pesticide respirators & 7 & 4.9 \\
\hline \multicolumn{3}{|l|}{ Equipment used for application: } \\
\hline Knapsack sprayer & 127 & 89.4 \\
\hline No equipment & 15 & 10.5 \\
\hline
\end{tabular}

crops. Pesticides of the triazole, ethylbenzalkonium chloride, diphenyl ether and oxime methylcarbamate groups are typically used in tomato crops. Although the farmers use other pesticides, the organophosphorus chemical group is predominant in both coffee plantations and the preparation of the land for other crops.

Most of the products used by the farmers in the Conceição de Castelo region in their crops are imported. Among the pesticides used by these farmers, only the Fegatex brand that belongs to the ethylbenzalkonium chloride group is man-
Table 3. Socio demographic characteristics of rural workers.

\begin{tabular}{|c|c|c|}
\hline Variable & $\mathbf{N}$ & $\%$ \\
\hline \multicolumn{3}{|l|}{ Gender: } \\
\hline Male & 102 & 71.8 \\
\hline Female & 40 & 28.2 \\
\hline \multicolumn{3}{|l|}{ Age group: } \\
\hline $15-29$ & 27 & 19.0 \\
\hline $30-39$ & 33 & 23.3 \\
\hline $40-49$ & 23 & 16.2 \\
\hline 50 or older & 59 & 41.5 \\
\hline \multicolumn{3}{|l|}{ Educational level: } \\
\hline Up to 4 th grade & 78 & 55.0 \\
\hline 5 th to 8 th grade & 45 & 31.7 \\
\hline Complete secondary school & 18 & 12.6 \\
\hline Higher education & 1 & 0.7 \\
\hline \multicolumn{3}{|l|}{ Know what PPE is: } \\
\hline Yes & 41 & 28.9 \\
\hline No & 101 & 71.1 \\
\hline \multicolumn{3}{|l|}{ Smoking habit: } \\
\hline Never smoked & 131 & 92.2 \\
\hline Smokes up to 10 cigarettes/day & 9 & 6.4 \\
\hline Smokes more than 10 cigarettes/ & 1 & 0.7 \\
\hline day & 1 & 0.7 \\
\hline \multicolumn{3}{|l|}{ Former smoker } \\
\hline \multicolumn{3}{|l|}{ Alcohol consumption: } \\
\hline Never drinks & 106 & 74.6 \\
\hline Occasional consumption/small & 24 & 17.0 \\
\hline amount & 11 & 7.7 \\
\hline $\begin{array}{l}\text { Usual daily consumption of one to } \\
\text { two doses }\end{array}$ & 1 & 0.7 \\
\hline $\begin{array}{l}\text { Usual daily consumption of three } \\
\text { doses }\end{array}$ & & \\
\hline
\end{tabular}

ufactured in Brazil ${ }^{5}$. Because these products are essentially imported and despite the strict regulations imposed by the National Health Surveillance Agency (ANVISA) and other supervisory agencies, there is still a large release of such products because all of them are purchased in shops for farmers without any control of the purchased quantity ${ }^{4}$.

The pattern of pesticide use in Brazil and in the World is similar when comparing the classes and chemical groups applied in plantations. Triazole pesticides, such as tebuconazole and myclobutanil, are widely used in Europe and Canada ${ }^{3}$. The National Health and Nutrition Examination Survey (NHANES) has reported intoxications of Americans. Pesticide levels in carpet dust and pesticide metabolites in the urine of Washington state residents have increased in individuals who own homes near orchard fields and during the pesticide application season ${ }^{7}$. 
Table 4. Symptoms resulting from pesticide exposure.

\begin{tabular}{|c|c|c|}
\hline Symptoms & $\mathbf{N}$ & $\%$ \\
\hline Joint pain & 91 & 64.1 \\
\hline Headache & 94 & 66.2 \\
\hline Eye irritation & 83 & 58.4 \\
\hline Body (muscle) pain & 79 & 55.6 \\
\hline Cramps & 56 & 39.4 \\
\hline Blurred vision & 54 & 38.0 \\
\hline Tingling & 48 & 33.8 \\
\hline Nausea/gag reflex & 43 & 30.3 \\
\hline Changes in blood pressure & 40 & 28.1 \\
\hline Shortness of breath/dyspnoea & 40 & 28.1 \\
\hline Excessive sweating & 40 & 28.1 \\
\hline Heart palpitation & 39 & 27.4 \\
\hline Impaired digestion & 36 & 25.3 \\
\hline Hepatitis & 34 & 23.9 \\
\hline Lacrimation & 33 & 23.2 \\
\hline Salivation & 33 & 23.2 \\
\hline Agitation/irritability & 33 & 23.2 \\
\hline Gastric inflammation & 31 & 21.8 \\
\hline Dizziness/vertigo & 30 & 21.1 \\
\hline Abdominal pain & 26 & 18.3 \\
\hline Kidney disease & 26 & 18.3 \\
\hline Shivering & 20 & 14.0 \\
\hline Attention deficit & 19 & 13.3 \\
\hline Diarrhoea & 18 & 12.6 \\
\hline Liver Diseases & 16 & 11.2 \\
\hline Skin lesions/"allergy" & 15 & 10.6 \\
\hline Sputum & 11 & 7.7 \\
\hline Cough & 10 & 7.0 \\
\hline Sputum & 11 & 7.7 \\
\hline Asthma & 9 & 6.3 \\
\hline Vomiting & 8 & 5.6 \\
\hline Arthrosis/osteoporosis & 5 & 3.5 \\
\hline Respiratory diseases & 4 & 2.8 \\
\hline Cardiovascular diseases & 2 & 1.4 \\
\hline Cancer & 2 & 1.4 \\
\hline Skin burns & 2 & 1.4 \\
\hline
\end{tabular}

In Brazil, the Program for Analysis of Pesticide Residues in Foods (PARA) investigates pesticide residues in food. Between 2001 and 2010, it was found that $48.3 \%$ of products from the field were positive at least one pesticide residue. Within this study were found residues of organophosphorus; triazoles; pyrethroids and carbamates ${ }^{3}$.

The European Food Safety Authority (EFSA) report describes that more than $97 \%$ of food in the EU contains pesticide residues within the legal limits ${ }^{24}$. In plant products, 137 different substances were found in measurable concentra- tions. Pesticide residues chlorpyrifos, cyprodinil, dithiocarbamates, fenhexamid, fludioxonil and tebuconazole were the most frequently detected in more than $4 \%$ of the analyzed samples ${ }^{24}$. Comparing the different regions of Brazil and the world it is noticed that some chemical groups of pesticides are used by rural workers independent of the country of origin.

The extensive use of such products has been considered dangerous and harmful to both the producer and the consumer ${ }^{5,11}$. Some European countries, such as Germany, have been considerably reducing the use of these products in rural areas. At the same time, the production of pesticide-free products known as "organic products" has increasingly grown in both farms and small production areas; these products are grown without the use of chemical pesticides; only management and the knowledge of mixed cropping are used to avoid using products with pesticides ${ }^{11}$.

It must be noted that working with and handling pesticides requires the use of personal protective equipment (PPE). The analysis of the questionnaire data reveals that the farmers from the Conceição de Castelo region are directly and indirectly exposed to pesticides (Table 2). In a brief analysis and by observing how the farmers work, it can be noted that almost all of the population do not properly use PPE: $51.4 \%$ of the 142 interviewed workers use only boots; $48.6 \%$ do not use any PPE; 6.3\% use gloves; $4.9 \%$ use protective clothing and pesticide respirators; and $1.4 \%$ use hats. A study conducted by Silva et al. ${ }^{25}$ in Campos Gerais in the Brazilian state of Minas Gerais revealed that $95 \%$ of respondents reported the use of full PPE, which does not occur in Conceição do Castelo in the state of Espírito Santo.According to the NHANES program, farmers in the United States are advised on the use of pesticides. However, even guidance suggests that many do not adequately use personal protective equipment and ignore the risk of direct and indirect contact with pesticides ${ }^{7}$. According to EFSA, rural workers observed in 2013 are better following the pesticide control and use standards due to the rigid control of the European program ${ }^{24}$.

The knapsack sprayer is the equipment used for pesticide application. During the preparation of the spray mix containing the pesticides, the workers spill it on both the equipment and their hands and clothes, which allows the pesticides to directly contact the skin. Products in powder form are easily blown towards the face of the worker who is preparing the product and towards the bodies of other people who are in the same area. 


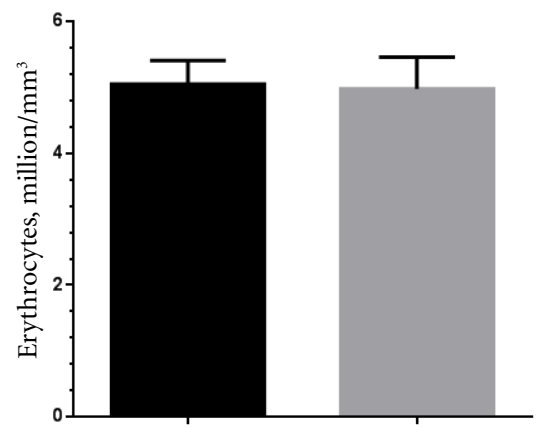

A
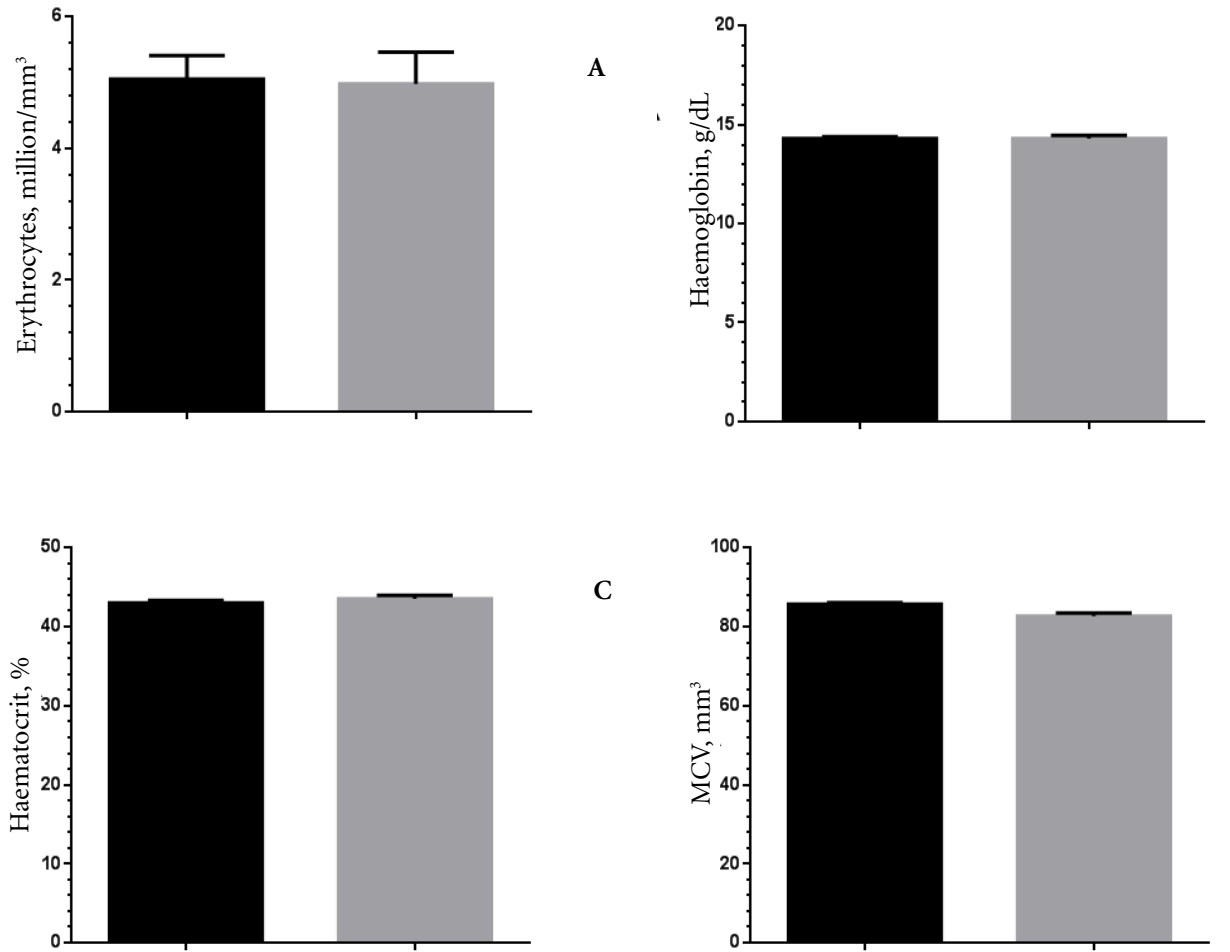

C
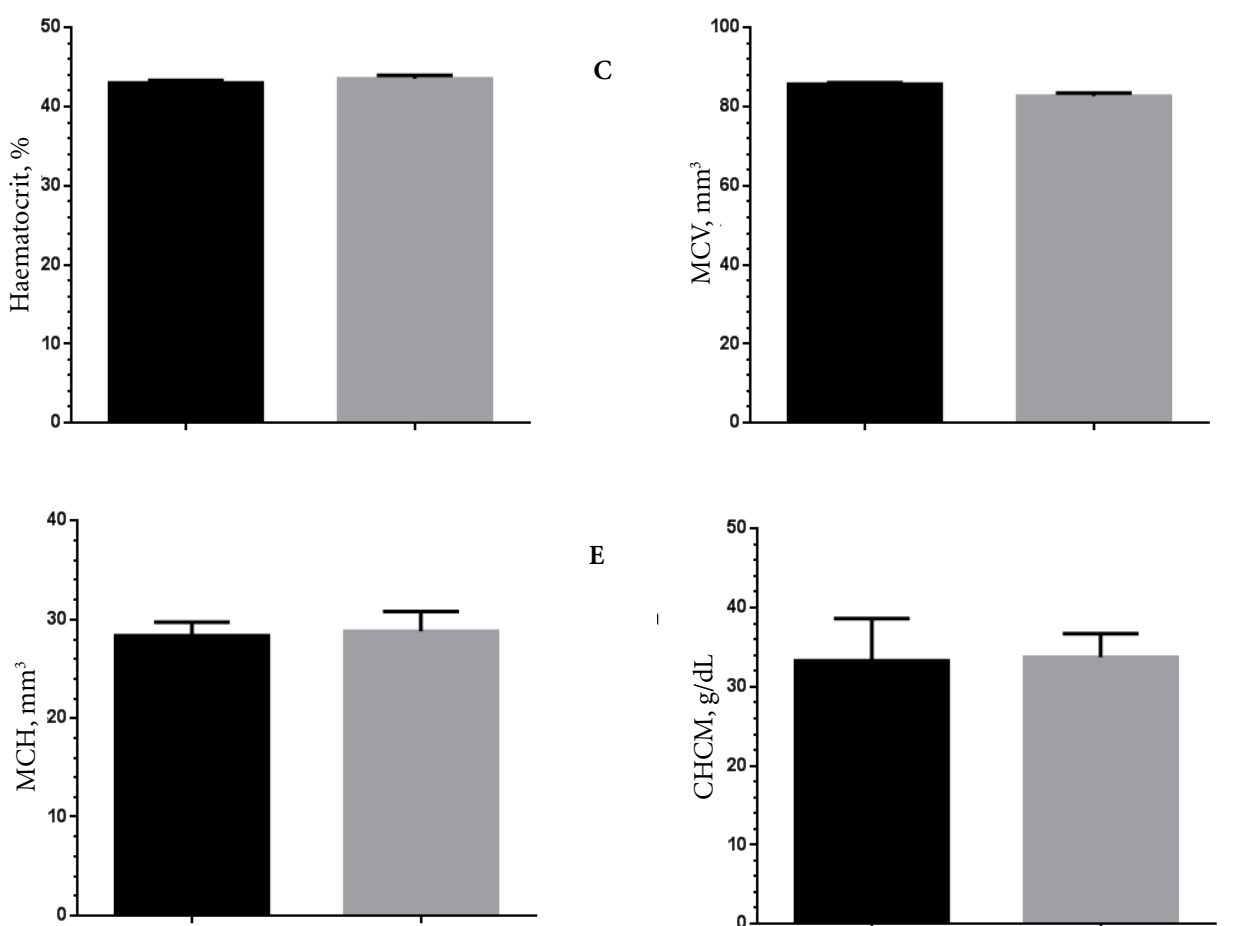

E

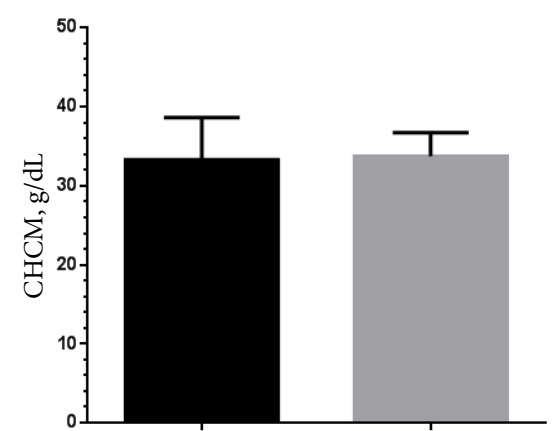

Figure 1. Hematological analysis of rural workers exposed to pesticides during the application period (direct exposure period) and during the harvest period (period without exposure). ${ }^{\star} \mathrm{p}$ value $<0.05,{ }^{* *} \mathrm{p}$ value $<0.01$, ${ }^{* * *} \mathrm{p}<0.001$ and $^{* * * *} \mathrm{p}<0.0001$.

The product is applied during daytime hours with high insolation. Some workers wash their equipment in rivers that are used for other purposes, such as bathing, consumption, and laundry.

The surfactants present in the organophosphorus are irritating, corrosive and toxic for living beings and cause irritation and problems in the eyes, skin, and respiratory and digestive tracts $^{26}$. These symptoms were observed in the data obtained in the evaluation of the Conceição de Castelo's farmers. Direct contact with skin, eyes and respiratory tracts leads to the acute poisoning of farmers. These consequences are evident according to the symptoms reported after the exposure, such as headache $(66.2 \%)$ and eye irritation (58.4\%).

The prolonged use of these pesticides may suggest symptoms of chronic poisoning. Among the respondents, the majority of them $(52.9 \%)$ have worked directly with pesticides for 11 to 20 


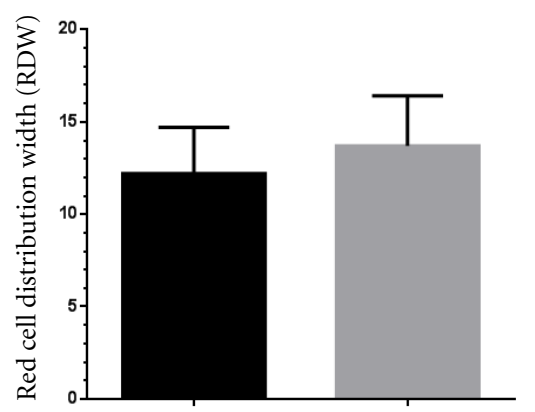

G
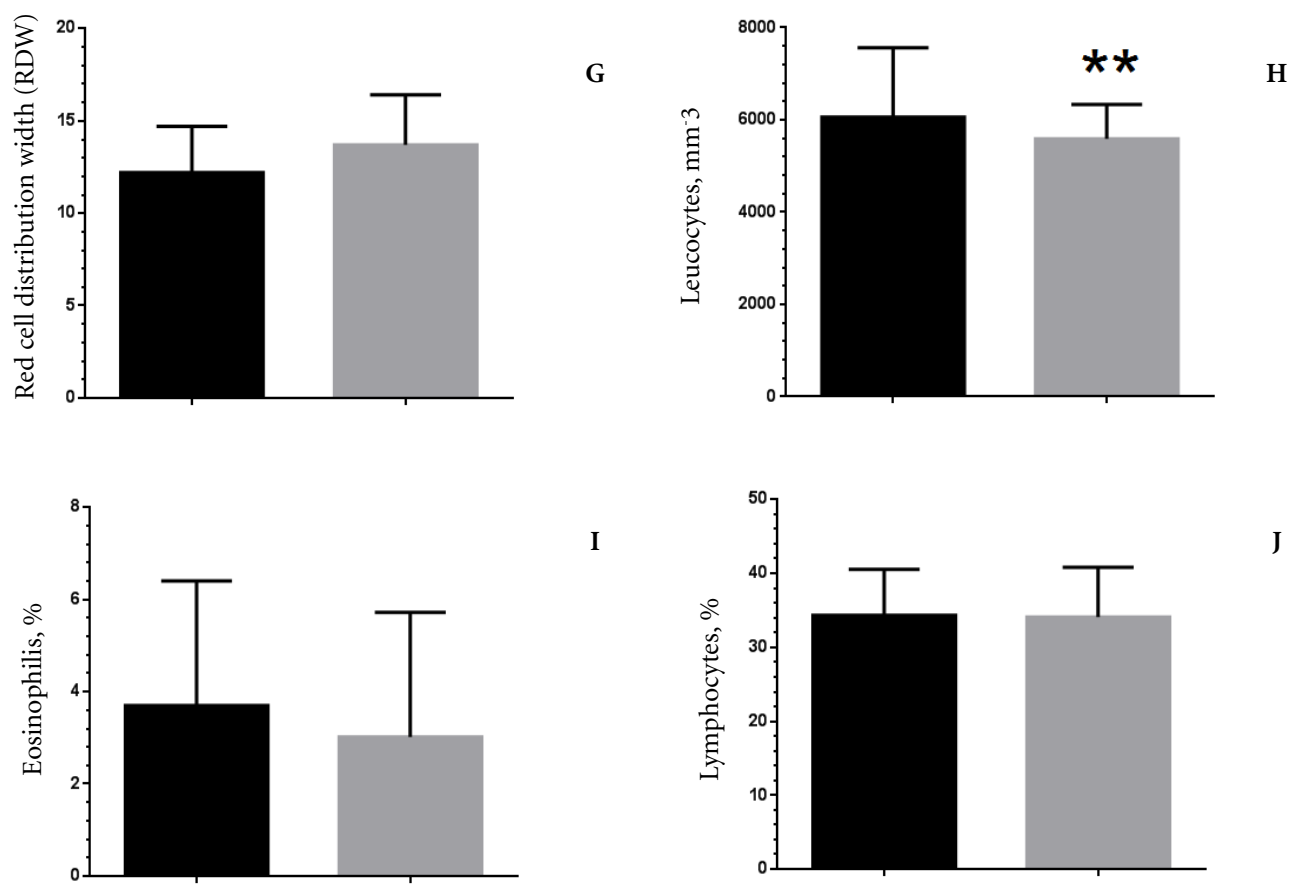

I
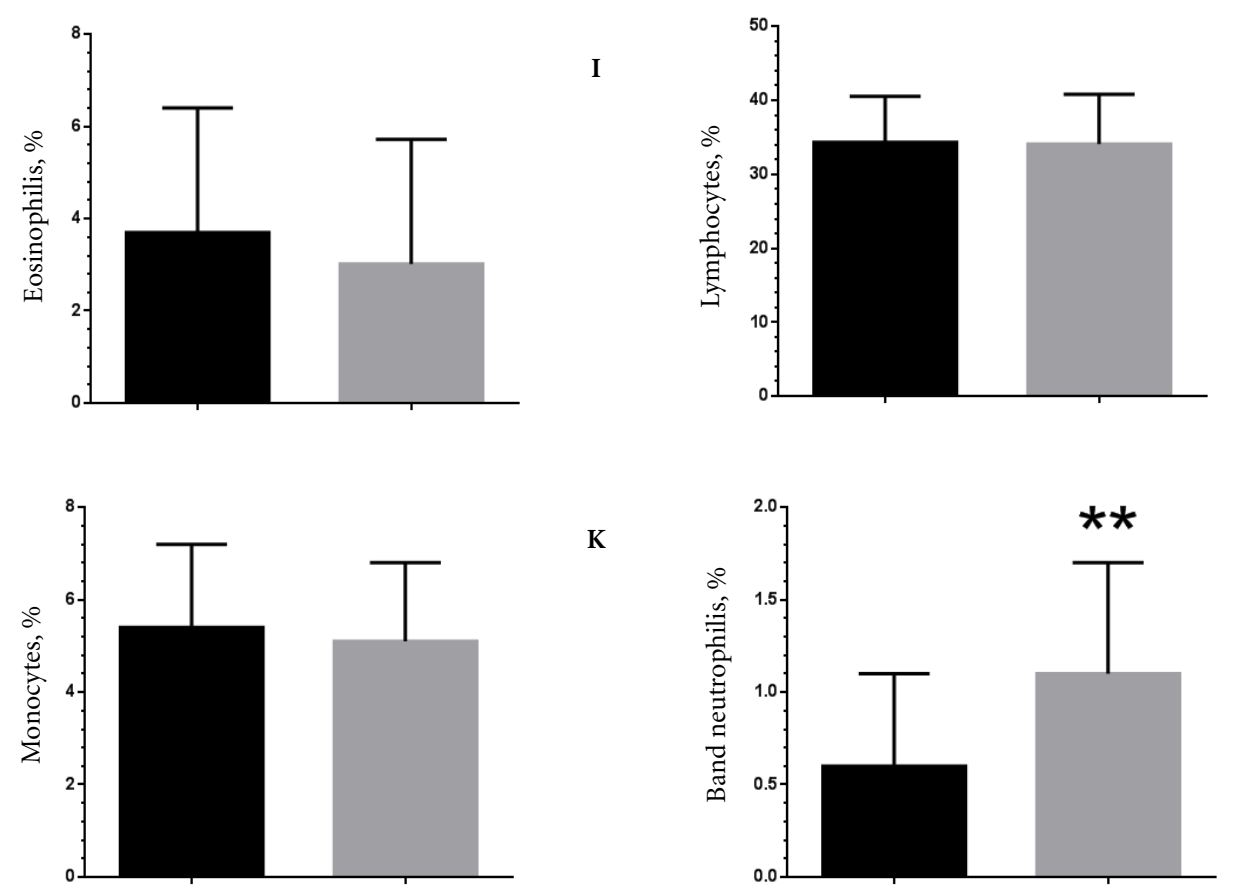

K

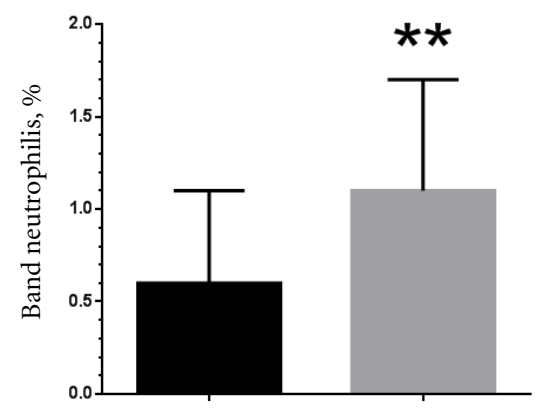

Figure 1. Hematological analysis of rural workers exposed to pesticides during the application period (direct exposure period) and during the harvest period (period without exposure). ${ }^{\star} \mathrm{p}$ value $<0.05,{ }^{* *} \mathrm{p}$ value $<0.01$, ${ }^{* * *} \mathrm{p}<0.001$ and ${ }^{* * * *} \mathrm{p}<0.0001$.

years; $26.7 \%$ have worked with them for 21 to 30 years and $20.4 \%$ for 02 to 10 years.

Among the respondents, $96.3 \%$ reported that they buy their pesticides in the municipality of Conceição do Castelo. This municipality has a transfer station for the disposal of empty containers. However, only $49.3 \%$ of the farmers deliver these containers to the transfer station, while $20.4 \%$ burn them and $45.7 \%$ store and reuse them to transport water to be used for pesticide application and to store other utensils. Additionally, some farmers store both empty containers and containers with pesticides at home, which exposes the entire family. These results differ from those obtained by Faria et al. ${ }^{27}$ in a study conducted in the municipality of Bento Gonçalves in the Brazilian state of Rio Grande do Sul, where most workers handed over 

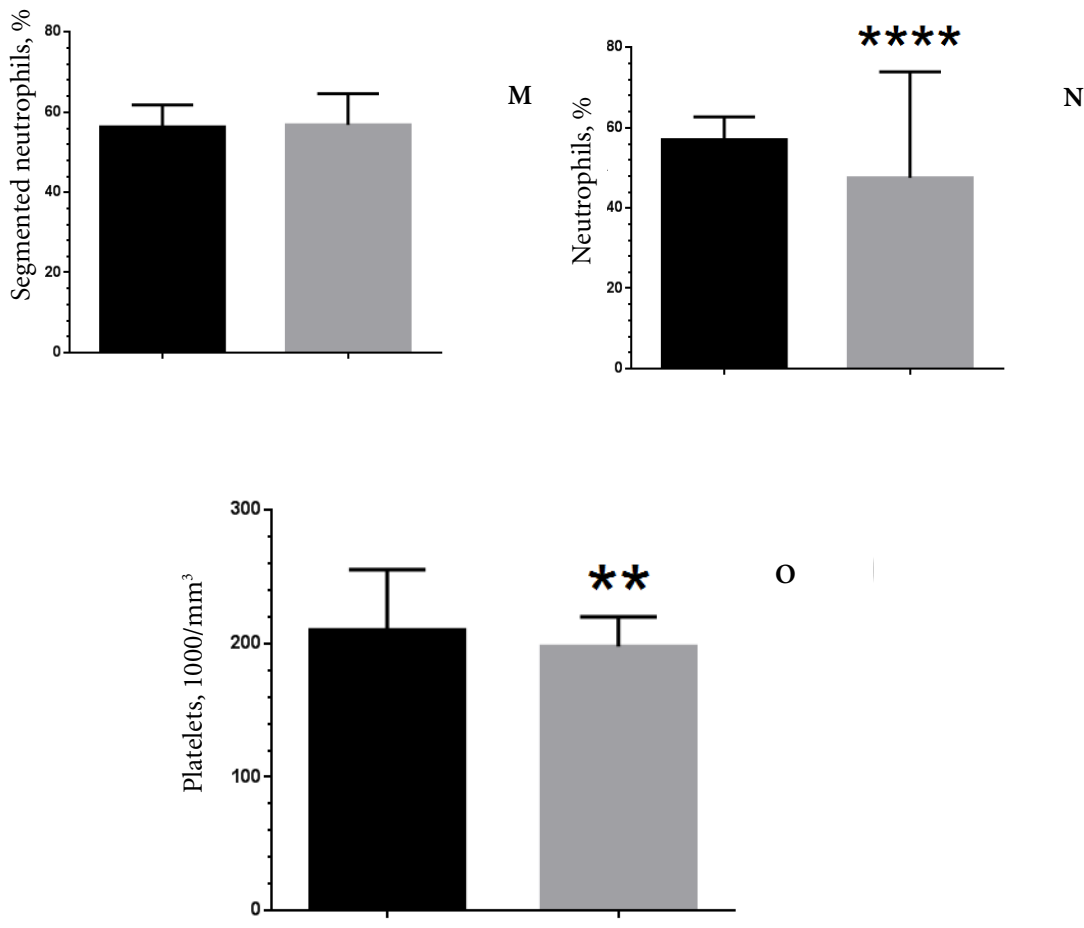

Figure 1. Hematological analysis of rural workers exposed to pesticides during the application period (direct exposure period) and during the harvest period (period without exposure). ${ }^{\star} \mathrm{p}$ value $<0.05,{ }^{* *} \mathrm{p}$ value $<0.01$, ${ }^{* * *} \mathrm{p}<0.001$ and ${ }^{* * *} \mathrm{p}<0.0001$.

the containers for selective collection (86.3\%) and received copies of agronomic prescriptions $(84.6 \%)^{27}$. The lack of a public policy regarding the disposal of these materials and information, in the municipality of Conceição do Castelo, can facilitate the development of diseases associated with contact with pesticides.

Among the rural workers, $96.5 \%$ do not receive an agronomic prescription and may be using the pesticides incorrectly, namely by using excessive amounts and then contaminating the environment. Only $3.5 \%$ of the workers receive an agronomic prescription, and $82.4 \%$ receive technical guidelines about how to use the pesticides from the vendors, who are not experts; therefore, inappropriate purchases and prescriptions for problems encountered on their farms might be obtained.
According to the interviewed farmers, during the purchase of the pesticides, the vendors provide information or guidance on how to handle the pesticides only if the buyer requests it. Some farmers also receive guidance from friends, neighbours or other individuals working in the properties.

The majority of the individuals exposed to pesticides are men $(71.8 \%$ of the interviewed population) (Table 3$)$. According to regulatory standard 31 (NR-31) on health and safety in agricultural work, item 31.8 prohibits children under 18 , individuals older than 60 , and pregnant women to directly or indirectly work with pesticides ${ }^{28}$. Within the group of individuals older than 50 years, individuals aged 60 to 82 years were identified, while $19.0 \%$ of the population was aged 15 to 29 years. These data serve as a warning because these individuals are more sus- 
ceptible to poisoning resulting from exposure to these pesticides because they are more sensitive and have low immunity.

According to the study, $71.1 \%$ of the respondents do not know what PPE is. The interview results indicate that many of these individuals have an educational level up to the 4 th grade $(55.0 \%)$, and some have completed primary education. This factor serves as an alert for the implementation and promotion of an educational system that meets the needs of the farming communities because the lack of information is due to the low level of education, thus impairing the individual's capacity to read and understand the severity of being exposed to materials harmful to both their health and the environment.

The pesticides labels explain how to use them, application doses, storage, transportation and some health problems resulting from incorrect use of the products. Because the population has a low educational level, individuals may ignore the information and use the pesticides without the necessary level of care, improperly and without protection, thus causing various health problems.

It is also noted that most workers do not consume alcohol and do not smoke, which is a positive aspect of this community. Alcohol consumption along with pesticide poisoning causes high levels of liver and lung overload and neurotoxicity ${ }^{2}$. In Bento Gonçalves in the state of Rio Grande do Sul, alcohol consumption was reported by $17.8 \%$ of men and $14.3 \%$ of women from rural areas ${ }^{27}$.

Exposure to pesticides for long periods can result in several liver, neural, and renal physiological disorders ${ }^{29}$. To determine possible physiological disorders due to the exposure to pesticides, the farmers from the Conceição do Castelo region were assessed for symptoms resulting from acute and chronic poisoning by pesticides (Table 4). In fact, analysis of the data for the assessed rural community reveals that these workers also have some of the symptoms described above.

The change in respiratory, eye problems, gastrointestinal disorders and skin changes are found in workers who use pesticide sprayers ${ }^{30}$. The presence of different symptoms and conditions suggests the need for clinical monitoring of these individuals. The results suggest that the 142 rural workers interviewed have symptoms of chronic intoxication, due to exposure to pesticides for long periods. The symptoms described in Table 4 can be related to other disorders, but exposure to pesticides can also increase or amplify any such damage.
Human exposure to pesticides is a serious public health problem worldwide, especially in developing countries ${ }^{31}$. The inappropriate use of pesticides has had several consequences for the health of rural workers ${ }^{32,33}$.

Poisoning is not always reported in Conceição do Castelo because of the lack of laboratories with the necessary technology for quantifying and determining pesticide-derived substances in the blood. According to internal records of the epidemiological surveillance department of Conceição de Castelo, 33 cases of poisoning were reported between January 2002 and September 2013. In 2010, a total of 376 cases of pesticide poisoning were reported by the Toxicology Control Centre (TOXCEN), while 218 cases were reported by the Information System for Notifiable Diseases (SINAN) in the state of Espírito Santo.

It is believed that the number of pesticide poisoning cases is higher because there are no trained professionals in the rural areas to accurately diagnose them. Accordingly, healthcare teams need to be trained to improve diagnosis and to introduce methodologies effective in confirming that poisoning has occurred.

Including professionals with such expertise in family health teams, especially in those covering families from rural areas, for recognising and managing the poisoning cases and also disseminating guidelines for preventing or reducing the effects of pesticide exposure are possibilities for minimising the impacts of the effects resulting from the exposure to pesticides. Other proposals may include partnerships with education entities that involve the training of rural school teachers about pesticides, expanding the scope of the guidelines for future farmers.

Among the 142 respondents, 22 workers were randomly selected for haematological analysis. Haematological analyzes suggest no changes in the characteristics and total number of red blood cells (Figure 1A-F). Rats exposed to pesticides show results, with decreases in erythrocyte count and mean corpuscular volume (MCV) ${ }^{34}$. Erythrocyte count from $5.05 \mathrm{million} / \mathrm{mm}^{3}$ to $4.98 \mathrm{mil}$ lion $/ \mathrm{mm}^{3}$ is within the normal range. The $M C V$ from $85.62 \mathrm{~mm}^{3}$ to $82.64 \mathrm{~mm}^{3}$ can suggest a reduced synthesis of haemoglobin in the erythrocytes that results in smaller cells (Figure 1D).

However, the red cell distribution width (RDW) analyzed suggests changes in red blood cells, although not statistically significant (Figure $1 G)$. The RDW has been reported as an independent predictor of 30-day mortality in patients with organophosphorus poisoning ${ }^{35}$. Some stud- 
ies have shown that increasing RDW is associated with the development of coronary artery disease, heart failure, stroke, peripheral artery disease ${ }^{36-39}$. The RDW also can also be related neurohormonal activation, renal dysfunction, thyroid disease, liver dysfunction, nutritional deficiencies, bone marrow dysfunction, inflammatory diseases, chronic systemic inflammation or acute ${ }^{35}$. The RDW cannot give accurate information to physicians on the inflammatory state and indication of the prognosis of patients with no other inflammatory indicators ${ }^{40}$.

In the case of rural workers, should be associated with the symptomatology observed with the values found here RDW serving with alert to the development of diseases associated with contact with organophosphorus. RDW should be evaluated and followed up with other serum inflammatory markers to determine inflammatory status and prognostic indication of patients ${ }^{40}$. In parallel, biochemical markers of transaminases (AST and ALT) and BChE were analyzed in the blood of rural workers. The values of AST, ALT and BChE were: $15.3 \pm 3.9 \mathrm{U} / \mathrm{L}$ (direct exposure period) and $14.9 \pm 4.5 \mathrm{U} / \mathrm{L}$ (period without exposure); $12.2 \pm .5$ and $13.1 \pm 3.9 \mathrm{U} / \mathrm{L} ; 6.92 \pm 2.3$ (direct exposure period) and 7.12 $\pm 3.9 \mathrm{U} / \mathrm{L}$ (period without exposure). In both periods the results did not present relevant variations.

The RDW levels are higher in rural workers of Conceição do Castelo. High levels of RDW may be related intense microcytosis; agglutinins of RBCs; production of red blood cells ineffective as iron deficiency; Vitamin B12 or folate; high lymphocyte count; the presence of giant platelets; platelet aggregates; thrombotic thrombocytopenic purpura; underactive thyroid, kidney, liver, and bone marrow; and inflammatory bowel diseases ${ }^{41}$. RDW above 13\% may indicate a high degree of poisoning ${ }^{35}$. Workers investigated possessed values near $13 \%$, indicating a high degree of poisoning.

One possibility to increase the RDW is subclinical chronic inflammation that can occur by a variety of mechanisms. In case of inflammatory processes there are changes in leucocytes. The role of the immune system is to prevent tumour onset and progression. Therefore, studies have been conducted to address the effect of pesticides on different parameters of immunity ${ }^{34}$. In vivo and in vitro experiments have shown significant reductions in the cellular and humoral immune responses in cases of glyphosate exposure ${ }^{42}$.

According to the description of the symptoms presented by rural workers as a result of pesticide use, was expected to find changes in the number of leucocytes. During the exhibition period it was found that the number of white blood cells the patient was close to normal. However the harvest period, a reduction in the number of leucocytes (Figure $1 \mathrm{H}$ ) was verified. Analyzing leucocyte series, it was found that lymphocytes, monocytes and segmented neutrophils have not changed (Figure $1 \mathrm{~J}, \mathrm{~K}$, and $\mathrm{M}$ ). It was not found the presence of basophils, atypical lymphocytes, myelocytes, metamyelocytes, blasts in farm workers. Figure 1-I suggests that there is a reduction in the number of eosinophils, but according to statistical analysis this difference cannot be confirmed.

In the 90s, trichlorphon was reported as organophosphorus insecticide capable of inducing leukopenia and decrease the amount of neutrophils and phagocytic capacity ${ }^{43}$. The data, described in Figure 1, suggest decrease in the amount of leucocytes and neutrophils. Possibly, this reduction should be associated with exposure to different pesticides such as Roundup, which have in their composition different organophosphorus. In relation to neutrophils, it was found that the amount of band neutrophils increased (Figure 1L) while segmented neutrophils remained proportional (Figure $1 \mathrm{M}$ ).

There was a decrease in the number of neutrophils (Figure 1N). Little is known about the mechanisms involving metabolic and phagocytic capacity in neutrophils as well as the production of proinflammatory cytokines when there is chronic poisoning organophosphorus ${ }^{44}$. Chronic exposure to organophosphorus may modulate cholinergic antiinflammatory pathway, leading to activation of muscarinic receptors and thereby modulating the immune-regulatory function of the vagal nerve, the efferent vagal activation of nerve fibers ${ }^{44,45}$. The decrease of the levels of neutrophils and eosinophils should be monitored because these cells are involved in the body's defense system.

According to figure 10, platelets were within the normal range. However, the initial value of $210,136.3 \mathrm{~mm}^{3}$ decreased to $197,857.1 \mathrm{~mm}^{3}$ after exposure. Platelet activity is considered an initial response in the regulation of haemostasis; their most important functions include adhesion, aggregation, and secretion. In addition, the procoagulant proteins are involved in haemostasis consolidation. Studies have shown an inhibition of platelet aggregation, with a decrease in ATP secretion by platelets caused by the mechanism involved in the anti-platelet aggregation effect of glyphosate ${ }^{46}$. Studies with rural workers using sprays of pesticides organophophorus report- 
ed that there was a significant decrease in mean haemoglobin, haematocrit and platelet count at the end of the day after use of sprays by rural workers ${ }^{47}$. In theory, such factors could favour low immunity, with a higher chance of bleeding and other factors associated with haematological changes resulting in mild and severe medical conditions in rural workers.

The low level of education of rural workers contributes to misuse of pesticides. The government and environmental organizations should promote actions directed to rural workers so that those using pesticides rationally without harming the environment. It was also observed that some individuals showed symptoms of acute and chronic poisoning. Haematological results show a significant variation which demonstrates the need for monitoring of rural workers to monitor haematological disorders and other diseases as a result of direct contact with organophosphorus.

Rural workers associate with Roundup other commercial products like Aminol, Gramoxone, Folicur, Fegatex, Flex, Targa, True, Lannate. These pesticides are of different chemical groups
(Table 1) and may act in an additive or synergistic manner on toxicity. Within the composition of these pesticides are also carbamates, triazole and others. The Gramoxone pesticide, for example, has 1,1'-dimethyl-4,4'-bipyridine-dichloride (Paraquat) in its composition and is associated with many problems of intoxication around the world, causing respiratory problems and neurological damage ${ }^{48}$. In the long term, the use of Gramoxone in conjunction with Roundup could lead to increased amplification of hematological and neurological injuries for any rural community that is in direct and indirect contact with these pesticides ${ }^{49}$.

The results suggest the necessity of implementation and promotion of an educational system that meets the needs of farming communities and the need to provide appropriate training for health workers in order to avoid future impacts on community health and the environment. These precepts are widely discussed not only by the international academic community but also by the government in order to reduce the use of pesticides in agriculture.

\section{Colaborators}

J Dalbó contributed in the development of the project, in the review of the literature, analysis of the data and writing of the article, LA Filgueiras collaborated in the data analysis and revision of the article and AN Mendes contributed in the development of the project, literature review, data analysis and writing of the article.J Dalbó contributed in the development of the project, in the review of the literature, analysis of the data and writing of the article, LA Filgueiras collaborated in the data analysis and revision of the article and AN Mendes contributed in the development of the project, literature review, data analysis and writing of the article. 


\section{References}

1. Selmi GFR, Trapé AZ. Health protection for rural workers: the need to standardize techniques for quantifying dermal exposure to pesticides. Cad Saude Publica 2014; 30(5):952-960.

2. Jacobson LSV, Hacon SS, Alvarenga L, Goldstein RA, Gums C, Buss DF, Leda LR. Pomeranian community and the use of pesticides: an unknown reality. Cien Saude Colet 2009; 14(6):2239-2249.

3. Jardim ANO, Caldas ED. Brazilian monitoring programs for pesticide residues in food - Results from 2001 to 2010. Food Cont 2012; 25(2):607-616.

4. Brasil. Agência Nacional de Vigilância Sanitária (Anvisa). Programa de análise de resíduos de agrotóxicos em alimentos (PARA). Brasília: Anvisa; 2014.

5. Rigotto RM, Vasconcelos DP, Rocha MM. Pesticide use in Brazil and problems for public health. Cad Saude Publica 2014; 30(7):1360-1362.

6. Costa LG. Current issues in organophosphate toxicology. Clin Chim Acta 2006; 366(1-2):1-13.

7. Roberts JR, Karr CJ. Pesticide exposure in children. Pediatrics 2012; 130:e1765-88.

8. Lewis J, Gehman E, Baer C, Jackson D. Alterations in gene expression in Caenorhabditis elegans associated with organophosphate pesticide intoxication and recovery. BMC Genomics 2013; 14:291.

9. Bigley AN, Raushel FM. Catalytic Mechanisms for Phosphotriesterases. Biochim Biophys Acta 2013; 1834(1):443-453.

10. Ross SM, McManus IC, Harrison V, Mason O. Neurobehavioral problems following low-level exposure to organophosphate pesticides: a systematic and meta-analytic review. Crit Rev Toxicol 2013; 43(1):21-44.

11. Eddleston M, Chowdhury FR. Pharmacological treatment of organophosphorus insecticide poisoning: the old and the (possible) new. Br J Clin Pharmacol 2016; 81(3):462-470

12. Weinbroum AA. Pathophysiological and clinical aspects of combat anticholinesterase poisoning. $\mathrm{Br} \mathrm{Med}$ Bull 2004; 72:119-133.

13. Bayrami M, Hashemi T, Malekirad AA, Ashayeri $\mathrm{H}$, Faraji F, Abdollahi M. Electroencephalogram, cognitive state, psychological disorders, clinical symptom, and oxidative stress in horticulture farmers exposed to organophosphate pesticides. Toxicol Ind Heal 2012; 28(1):90-96.

14. Blanc-Lapierre A, Bouvier G, Garrigou A, Canal-Raffin M, Raherison C, Brochard P, Baldi I. Chronic central nervous system effects of pesticides: state-of-theart. Rev Epidemiol Sante Publique 2012; 60(5):389-400.

15. King AM, Aaron CK. Organophosphate and carbamate poisoning. Emerg Med Clin North Am 2015; 33(1):133-151.

16. Hove-Jensen B, Zechel DL, Jochimsen B. Utilization of glyphosate as phosphate source: biochemistry and genetics of bacterial carbon-phosphorus lyase. Microbiol Mol Biol Rev 2014; 78(1):176-197.

17. Sánchez-Santed F, Colomina MT, Hernández EH. Organophosphate Pesticide exposure and neurodegeneration. Cortex 2015; 74:417-426.

18. Richardson RJ, Hein ND, Wijeyesakere SJ, Fink JK, Makhaeva GF. Neuropathy target esterase (NTE): overview and future. Chem Biol Interact 2013; 203(1):238-244
19. Casida JE, Durkin KA. Neuroactive insecticides: targets, selectivity, resistance, and secondary effects. Annu Rev Entomol 2013; 58:99-117.

20. Araoud M, Neffeti F, Douki W, Hfaiedh HB, Akrout M, Hassine M, Najjar MF, Kenani A. Adverse effects of pesticides on biochemical and haematological parameters in Tunisian agricultural workers. J Expo Sci Env Epidemiol 2012; 22(3):243-247.

21. Silva MR, Campos ACE, Bohm FZ. Pesticides and their impacts for continental aquatic ecosystems. SaBios Rev Saúde e Biol 2013; 8:46-58.

22. Niva CC, Niemeyer JC, Júnior FMRDS, Nunes MET, Sousa DL, Aragão CWS, Sautter KD, Espindola EG, Sousa JP, Römbke JJ. Soil ecotoxicology in Brazil is taking its course. Env Sci Pollut Res Int 2016; 23(11):11363-11378.

23. Bradberry SM, Proudfoot AT, Vale JA. Glyphosate poisoning. Toxicol Rev 2004; 23(3):159-167.

24. Authority EFS. The 2013 European Union report on pesticide residues in food. EFSA J 2015; 13(3):4038.

25. Silva AS, Pezza L, Pezza HR. Flow-injection spectrophotometric determination of glyphosate in commercial formulations of herbicides. Quím Nov 2012; 35(1):114-118.

26. Schinasi L, Leon ME. Non-Hodgkin lymphoma and occupational exposure to agricultural pesticide chemical groups and active ingredients: a systematic review and meta-analysis. Int J Env Res Public Heal 2014 11(4):4449-4527.

27. Faria NMX, Rosa JAR, Facchini LA. Poisoning by pesticides among family fruit farmers, Bento Gonçalves, Southern Brazil. Rev Saude Publica 2009; 43(2):335344.

28. Silva JM, Novato-Silva E, Faria HP, Pinheiro TM. Pesticides and work: a dangerous combination for the Brazilian agricultural workers health. Cien Saude Colet 2005; 10(4):891-903.

29. Guyton KZ, Loomis D, Grosse Y, El Ghissassi F, Benbrahim-Tallaa L, Guha N, Scoccianti C, Mattock H, Straif K. Carcinogenicity of tetrachlorvinphos, parathion, malathion, diazinon, and glyphosate. Lancet Oncol 2015; 16(5):490-491.

30. Malekirad AA, Faghih M, Mirabdollahi M, Kiani M, Fathi A, Abdollahi M. Neurocognitive, mental health, and glucose disorders in farmers exposed to organophosphorus pesticides. Arh Hig Rada Toksikol 2013; 64(1):1-8.

31. Mostafalou S, Abdollahi M. Pesticides and human chronic diseases: evidences, mechanisms, and perspectives. Toxicol Appl Pharmacol 2013; 268(2):157177.

32. Konradsen F, van der Hoek W, Cole DC, Hutchinson G, Daisley H, Singh S, Eddleston M. Reducing acute poisoning in developing countries--options for restricting the availability of pesticides. Toxicology 2003; 192(2-3):249-261.

33. Peñaflor M, Bento JMS. Herbivore-Induced Plant Volatiles to Enhance Biological Control in Agriculture. Neotrop Entomol 2013; 42(4):331-343.

34. Evans JA, Tranel PJ, Hager AG, Schutte B, Wu C, Chatham LA, Davis AS. Managing the evolution of herbicide resistance. Pest Manag Sci 2015; 72(1):74-80. 
35. Kang C, Park IS, Kim DH, Kim SC, Jeong JH, Lee SH, Lee SB, Jung SM, Kang TS, Lee KW. Red cell distribution width as a predictor of mortality in organophosphate insecticide poisoning. Am J Emerg Med 2014; 32(7):743-746.

36. Balta S, Demirkol S, Cakar M, Ardic S, Celik T, Demirbas S. Red cell distribution width: a novel and simple predictor of mortality in acute pancreatitis. Am J Emerg Med 2013; 31(6):991-992.

37. Fatemi O, Paranilam J, Rainow A, Kennedy K, Choi J, Cutlip D, Pencina M, Berger PB, Cohen DJ, Kleiman NS. Red cell distribution width is a predictor of mortality in patients undergoing percutaneous coronary intervention. J Thromb Thrombolysis 2013; 35(1):5764.

38. Fici F, Celik T, Balta S, Iyisoy A, Unlu M, Demitkol S, Yaman H, Brambilla G, Kardesoglu E, Kilic S, Yokusoglu M, Grassi G. Comparative effects of nebivolol and metoprolol on red cell distribution width and neutrophil/lymphocyte ratio in patients with newly diagnosed essential hypertension. J Cardiovasc Pharmacol 2013; 62(4):388-393.

39. Kim CH, Park JT, Kim EJ, Han JH, Han JS, Choi JY, Han SH, Yoo TH, Kim YS, Kang SW, Oh HJ. An increase in red blood cell distribution width from baseline predicts mortality in patients with severe sepsis or septic shock. Crit Care 2013; 17:R282.

40. Balta S, Aparci M, Ozturk C, Demirkol S, Celik T. Red cell distribution width in organophosphate exposure patients. Am J Emerg Med 2014; 32:1132.

41. Senthilkumaran S, Menezes RG, Ananth C, Thirumalaikolundusubramanian P. Red cell distribution width in organophosphate insecticide poisoning: utility or futility? Am J Emerg Med 2014; 32:937.

42. Blakley BR. Effect of roundup and tordon $202 \mathrm{C}$ herbicides on antibody production in mice. Vet Hum Toxicol 1997; 39(4):204-206.

43. Siwicki AK, Cossarini-Dunier M, Studnicka M, Demael A. In vivo effect of the organophosphorus insecticide trichlorphon on immune response of carp $(\mathrm{Cy}-$ prinus carpio). II. Effect of high doses of trichlorphon on nonspecific immune response. Ecotoxicol Env Saf 1990; 19(1):99-105.
44. Zabrodskii PF, Grishin VA, Borodavko VK. Mechanism of suppression of phagocytic and metabolic activity of neutrophils and production of proinflammatory cytokines during chronic poisoning with organophosphorus compounds. Bull Exp Biol Med 2013; 155(4):464-466.

45. Oke SL, Tracey KJ. From CNI-1493 to the immunological homunculus: physiology of the inflammatory reflex. J Leukoc Biol 2008; 83(3):512-517.

46. Neiva TJC, Moraes ACR, Schwyzer R, Vituri CL, Rocha TRF, Fries DM, Silva MA, Benedetti AL. In vitro effect of the herbicide glyphosate on human blood platelet aggregation and coagulation. Rev. Bras. Hematol. Hemoter. 2010; 32(4):291-294.

47. Rastogi SK, Singh VK, Kesavachandran C, Jyoti, Siddiqui MKJ, Mathur N, Bharti, R S. Monitoring of plasma butyrylcholinesterase activity and hematological parameters in pesticide sprayers. Indian J Occup Env Med 2008; 12(1):29-32.

48. Gil H, Hong J-R, Jang S-H, Hong S-Y. Diagnostic and Therapeutic Approach for Acute Paraquat Intoxication. J Korean Med Sci 2014; 29(11):1441-1449.

49. Freire C, Koifman S. Pesticide exposure and Parkinson's disease: epidemiological evidence of association. Neurotoxicology 2012; 33(5):947-971.

Artigo apresentado em 01/08/2016

Aprovado em 28/09/2017

Versão final apresentada em 30/09/2017 